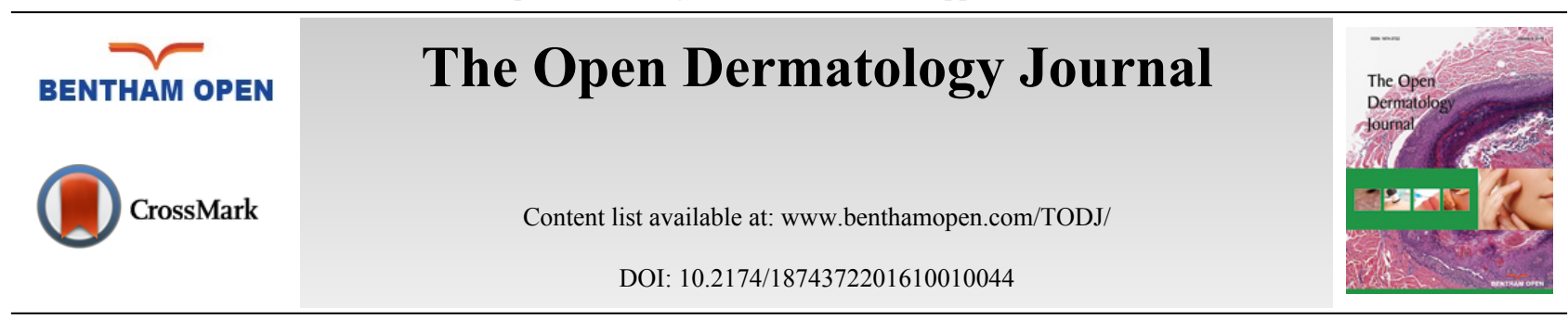

\title{
Nervous System Involvement in Lyme Borreliosis
}

\author{
Katarina Ogrinc and Vera Maraspin \\ Department of Infectious Diseases, University Medical Center Ljubljana, Slovenia
}

\begin{abstract}
Lyme neuroborreliosis (involvement of the central and/or peripheral nervous system due to infection with $B$. burgdorferi sensu lato) is the second most frequent manifestation of Lyme borreliosis in Europe, while it comprises the third most common expression of the disease in North America. Early Lyme neuroborreliosis, which is much better defined and far more common than late Lyme neuroborreliosis, is in Europe caused mainly by B. garinii and comprises the classic triad of meningitis, radiculoneuritis and/or cranial neuropathy, while in American patients subacute meningitis with or without cranial neuropathy is the most common manifestation. Among chronic forms of European Lyme neuroborreliosis peripheral neuritis associated with acrodermatitis chronic atrophicans is most frequently observed. A reliable diagnosis of borrelial central nervous system infection requires demonstration of lymphocytic pleocytosis and the evidence of borrelial infection of the central nervous system, established by intrathecal synthesis of specific antibodies and/or isolation of Borreliae from the cerebrospinal fluid. Treatment with oral doxycycline, or parenteral penicillin or third generation cephalosporins (most frequently ceftriaxone) for $2-4$ weeks is efficient in the majority of patients..
\end{abstract}

Keywords: Borrelia burgdorferi sensu lato, Borrelia garinii, chronic meningitis, cranial neuropathy, encephalomyelitis, meningitis, meningo-radiculoneuritis, peripheral neuropathy.

\section{INTRODUCTION}

Lyme borreliosis is a multi-systemic infectious disease caused by the spirochete Borrelia burgdorferi sensu lato ( $B$. burgdorferi s.1.), and is transmitted by Ixodes species ticks [1]. The most frequent manifestation of the disease is erythema migrans (EM) - a characteristic erythematous skin lesion, that develops days to weeks after infection at the site of a tick bite, expands over time, often with central clearing and reaches at least $5 \mathrm{~cm}$ in diameter [2, 3]. If hematogenous dissemination of the causative agent occurs, EM can be followed by multiple EM skin lesions or by nervous system or heart involvement, and later on by arthritis; late involvement of nervous system, joints, skin or the eye may also occur, but a complete presentation of the disease is extremely rare [4 - 6].

Lyme neuroborreliosis is the involvement of the central and/or peripheral nervous system due to infection with B. burgdorferi s.l. Before serodiagnostics was available, the diagnosis of Lyme neuroborreliosis was often missed, but after serological tests became widely available, the disease seems to become overdiagnosed, since the prevalence of seropositivity in endemic regions is high. Therefore, clinical manifestations of Lyme neuroborreliosis and strict diagnostic criteria have to be known and considered.

The aim of the manuscript is to give an overview of the field with special emphasis on clinical manifestations and diagnosis of Lyme neuroborreliosis.

\section{INCIDENCE AND ETIOLOGY}

Lyme borreliosis is the most common tick-borne infectious disease in countries with moderate climates in Eurasia and North America. The incidence of the disease is increasing in many countries, reaching up to several hundred per 100.000 inhabitants in some of them [7 - 9].

\footnotetext{
* Address correspondence to this author at Japljeva 2, 1525 Ljubljana, Slovenia; Tel: +386 1 5222110; Fax.: +386 1 52224564; Email: vera.maraspin@kclj.si
} 
According to the European data, the percentage of patients with Lyme neuroborreliosis, which is the second most frequent manifestation of Lyme borreliosis in Europe [5, 6, 10], differs from 3 [7, 11] to $16 \%$ [10], while in North America nervous system involvement is the third most frequent manifestation of the disease (following skin and joint manifestations), and is reported to occur in $12 \%$ of confirmed cases of Lyme borreliosis [8].

In Europe, Lyme borreliosis is caused most often by Borrelia afzelii (B. afzelii), followed by Borrelia garinii (B. garinii), Borrelia burgdorferi sensu stricto (B. burgdorferi s.s.) and only exceptionally by other Borrelia species, which leads to a broader clinical spectrum of the disease compared with North America, where only one species causes the disease in humans - B. burgdorferi s.s. [6]. The predominant etiologic agent of Lyme neuroborreliosis in European patients is $B$. garinii, followed by $B$. afzelii, rarely the cause is B. burgdorferi s.s. and only exceptionally $B$. valaisiana, B. bissettii or other borrelial species [12 - 20].

It has been found out that different Lyme borrelia genospecies and their geographical distribution are connected with particular clinical manifestations of Lyme borreliosis (most probably owing to their diverse organotropism), leading to some differences between the European and North American clinical picture of the illness [1, 4, 15, 21 - 23].

\section{CLINICAL MANIFESTATIONS}

Nervous system involvement usually appears weeks to months after the infection with B. burgdorferi s.l. (as a part of early disseminated Lyme borreliosis) and persists for several weeks to months, but may also develop later and persist longer. In some patients, other manifestations of borrelial infection can occur concurrently to Lyme neuroborreliosis, most often EM skin lesion [1, 10].

\section{EARLY LYME NEUROBORRELIOSIS}

European early Lyme neuroborreliosis is mostly an acute illness. The classic triad of distinct neurological manifestations consists of lymphocytic meningitis, cranial neuropathy (particularly involving the facial nerve), and radiculoneuritis (sensory or motor or both) [5, 6, 24 - 27].

The clinical picture of meningo-radiculoneuritis (Garin-Bujadoux-Bannwarth syndrome) has been a well known entity in Europe for several decades before the discovery of it's spirochetal etiology [28 - 31]. It is defined as a painful meningo-radiculoneuritis with or without peripheral or cranial nerve affection, caused by infection with B. burgdorferi s.l. In a substantial number of patients (34-64\%) EM may appear prior to or concomitant with neurological impairment [29, 26 - 36] Neurological symptoms typically develop 4-6 weeks after a tick bite or appearance of EM. The most pronounced clinical symptom is severe radicular pain which is burning, biting, boring or tearing in nature, is usually located on trunk, often belt-like, with possible radiation into extremities and almost unresponsive to usual analgesics. It seems to be more severe in elderly and intensifies during the night; patients may be deprived of sleep for several weeks. The location of pain very often matches the site of the tick bite or EM [28, 36, 37], although some reports didn't show any relation of the pain and tick bite and/or EM location [38]. Within 1-4 weeks after the beginning of radicular pain, further neurological complications may develop: cranial nerve palsies with the seventh cranial nerve being most commonly involved (sometimes bilateral), and/or sensory (dysesthesia, hyperesthesia) and/or motor deficit of involved region, which usually results in asymmetric pareses that are not always clinically prominent [32, 38, 39]. Other accompanying symptoms or signs, such as headache, fatigue, loss of appetite, photophobia or meningeal signs may be present $[34,35,40]$ but also neuropsychological symptoms, such as agitation, depression, anxiety, and restlessness have been observed [35]. Even in patients not treated with antibiotics, the pain resolves spontaneously after some weeks or months, but late stage of Lyme neuroborreliosis may follow. Meningoradiculoneuritis is much more often seen in European than American patients, affects predominantly adult population over 40 years of age, and for an unknown reason is extremely rare in children $[1,24,25]$.

The course of borrelial meningitis in adult European patients resembles mild but protracted viral meningitis with intermittent improvements and deteriorations. Clinically it manifests with mild and intermittent headaches, but in some patients headache may be prominent. Meningeal signs are only mildly expressed or absent, nausea, vomiting and fever are rare $[5,6,17,20,25,41]$. In children, isolated meningitis is more common than in adults $[4,5,36,42-44]$.

Among cranial neuropathies peripheral facial palsy is by far the most frequent manifestation. It can be unilateral or bilateral, can occur in association with meningo-radiculoneuritis (Garin-Bujadoux-Bannwarth syndrome), or is the first and the only clinical sign of Lyme neuroborreliosis. Clinically it is manifested as facial weakness or paralysis, eye problems (sore eye, lacrimation), taste disturbances, numbness, earache, and increased sensitivity to sound. In the 
majority of patients peripheral facial palsy of borrelial origin is associated with lymphocytic pleocytosis, indicating concomitant central nervous system (CNS) involvement, however symptoms and signs of meningitis are frequently absent $[1,6,45,46]$. Very early in the course of the disease, lymphocytic pleocytosis may be absent, but usually evolves in the following days. In Slovenia, which is a highly endemic country for Lyme borreliosis, borrelial infection was established in 22/114 (19.3\%) adult patients who presented with isolated peripheral facial palsy, and among them $12 / 22(54.5 \%)$ had lymphocytic pleocytosis [45]. Prognosis of borrelial peripheral facial palsy is good in antibiotictreated and also in untreated patients $[1,24]$; full or almost full recovery is expected in over $90 \%$ of patients [46]. In children, peripheral facial palsy occurs more often than in adults [4, 5, 43, 47, 48]. Involvement of all other cranial nerves has been described, with the exception of the olfactory nerve, but particularly III (oculomotor), VI (abducens), and VIII (vestibule-auditory) can be affected. These rare abnormalities are clinically manifested with diplopia and hearing loss and/or dizziness, respectively $[1,5,6,25,26,46]$.

It should be emphasized, that the above described typical clinical manifestations of early Lyme neuroborreliosis in European patients are due to $B$. garinii infection. However, it has been established, that the majority of patients with the B. afzelii infection of the CNS (proved by isolation), doesn't fulfill the diagnostic criteria for the European Lyme neuroborreliosis [17].

American Lyme neuroborreliosis almost always presents as subacute meningitis with or without associated cranial neuropathy (usually facial palsy). The disease develops within a few weeks to a few months after infection or the EM skin lesion. Headache, meningeal signs, migrating numbness or tingling, malaise, fatigue, myalgia and mild cognitive symptoms are common. Radicular symptoms may be present, but painful radiculitis is only occasionally seen in American patients [18, 24, 46, 49].

Some other neurological entities, like meningoencephalitis with cerebellar ataxia, paraplegic meningomyelitis, meningoencephalomyelitis, hemiparesis, exogenous psychosis and extrapyramidal syndrom were also described as possible manifestations of early Lyme neuroborreliosis, but it should be emphasized, that borrelial etiology in these clinical entities is extremely rare.

\section{LATE LYME NEUROBORRELIOSIS}

In general, nervous system involvement late in the course of Lyme borreliosis is much less common than in early disseminated stage of the disease [5, 27]; it represents less than 1-2\% of all patients with Lyme neuroborreliosis and is described primarily in Europe [36]. Central or peripheral nervous system can be affected.

Chronic borrelial infection of the CNS is a distinct clinical manifestation of the illness, defined as an active and long-lasting (more than 6 months) disease with persistent and marked cerebrospinal fluid (CSF) inflammation. Clinically it is manifested as chronic meningitis, progressive encephalomyelitis, or radiculomyelitis [36, 42, 50, 51].

Chronic meningitis is characterized by headache, malaise, sensorineural hearing loss and considerable weight loss.

Progressive encephalomyelitis, a rare form of chronic parenchymal borrelial infection with white matter involvement, manifests with spastic para or tetraparesis, ataxia, mental disorders, urinary bladder dysfunction, and sometimes with VII/VIII cranial nerve involvement [25, 50, 52, 53].

Acrodermatitis chronica atrophicans associated peripheral neuropathy, which is primarily caused by $B$. afzelii is the most common manifestation of late Lyme neuroborreliosis in Europe and occurs in more than half of patients with advanced acrodermatitis chronica atrophicans skin lesions [25, 54, 55]. It involves sensory nerves in affected parts of the skin (typically distal parts of extremities), is usually not associated with CSF inflammation, and is probably a result of direct extension of borrelial infection from the skin to the cutaneous nerves. Patients complain of hypesthesia, paresthesia and pain. The course of the neuropathy is usually mild and chronic, but even with appropriate antibiotic treatment, symptoms often persist. Peripheral neuritis without acrodermatitis chronica atrophicans is probably an extremely rare condition $[5,6,36]$.

Lyme encephalopathy is reported predominantly by American authors. It is marked by fatigue, impairment of memory and other intellectual functions, normal imaging and CSF findings, and is not due to direct Borrelia CNS involvement, as was often mistakenly thought, but is probably a condition mediated by cytokines and other neuroimmunomodulators in patients with non CNS borrelial manifestations [1, 27, 56 - 61]. Interpretation of this disorder is further complicated by the fact that a marked proportion of the general population experiences similar symptoms in the absence of any medical diagnosis [60]. 


\section{DIAGNOSIS}

The diagnosis of Lyme neuroborreliosis should be based on typical clinical picture and laboratory findings, including CSF pleocytosis, and positive serology, culture and/or PCR result [2, 3, 5, 17, 36, 62, 63].

Clinical diagnosis of early Lyme neuroborreliosis, which typically appears as lymphocytic meningitis, radiculoneuritis and cranial neuropathy, is straightforward, when the triad is complete or when at least one manifestation of the triad is accompanied by EM [1 - 3, 24, 63].

In patients with early Lyme neuroborreliosis, CSF shows pleocytosis up to several hundred leucocytes $x 10^{6} / \mathrm{L}$, with lymphocytic predominance, normal to moderately raised protein concentration, normal to slightly lowered glucose concentration, and inflammatory disturbances of the blood-brain barrier. In some patients with peripheral facial palsy of a recent onset, CSF pleocytosis may not be present. In chronic progressive encephalomyelitis, CSF lymphocytic pleocytosis, usually with activated B-lymphocytes and intrathecally synthesized specific IgG antibodies in CSF, have to be present to establish the diagnosis of late borrelial infection of the CNS, while in Lyme encephalopathy CSF cell count is normal $[56,57,59]$.

Borrelial etiology of CNS infection is proved by demonstration of intrathecal B. burgdorferi s.l. antibody synthesis, isolation of Borreliae from the CSF and/or demonstration of borrelial DNA in CSF sample [2, 3, 5, 17, 27, 63 - 69]. In everyday European clinical practice, the demonstration of the intrathecally synthesized borrelial antibodies is the most useful method to diagnose Lyme neuroborreliosis. For this purpose, the approach described by Reiber et al. is commonly used in which comparison of simultaneously measured serum and CSF concentrations of total and specific borrelial IgM and IgG antibodies is necessary [70 - 72]. The limitations of this approach are the absence of intrathecal B. burgdorferi s.l. specific antibody synthesis during the first few weeks of the disease, and persistence of the synthesis for several months or even years, also after appropriate antibiotic treatment $[2,3,5,17,63]$.

Isolation of the etiologic agent from the CSF is the most reliable microbiologic method for diagnosis of Lyme neuroborreliosis, but is technically demanding, expensive, time-consuming (results are obtained only after several weeks), available only in selected laboratories, and has a rather low sensitivity; in confirmed cases of Lyme neuroborreliosis, CSF culture is positive in $10-15 \%$ of patients $[17,20,73,74]$. PCR detection of borrelial DNA in CSF samples has low sensitivity, can't differentiate between living and dead borrelial cells, and the procedure is not standardized [63]. Seroconversion alone is rarely useful in practice, because at the time of neurological disease, the majority of patients are seropositive. Besides, seroconversion proves recent borrelial infection but not CNS involvement [5].

In recent years, studies of cytokines and chemokines have shown that the level of the CSF CXCL13 is significantly higher in patients with untreated Lyme neuroborreliosis than in patients with other inflammatory or non-inflammatory CNS diseases. CSF CXCL13 level may become a useful biomarker for the diagnosis and follow-up of Lyme neuroborreliosis [75 - 78].

Diagnosis of borrelial peripheral nervous system infection is even more difficult than demonstration of borrelial CNS involvement. Besides an objective evidence of the peripheral nervous system involvement (clinical, neurophysiologic and/or neuropathologic findings), borrelial infection of the involved nerves should be demonstrated; the presence of specific antibodies in serum is not enough for a reliable diagnosis. The proof that the borrelial infection really is the cause of the peripheral nervous system involvement depends upon the presence of concomitant CNS borrelial infection (with characteristic CSF findings) and/or the presence of other typical borrelial manifestations such as acrodermatitis chronica atrophicans [5]. Thus, in acrodermatitis chronica atrophicans associated peripheral neuritis, the diagnosis is established on the basis of characteristic neurological symptoms in the area of typical acrodermatitis chronica atrophicans skin lesion, positive borrelial serology (usually very high levels of specific antibodies in serum) and compatible histologic skin findings $[1,5,79,80]$. Sometimes additional diagnostic procedures, e.g. borrelial skin culture or PCR for detection of borrelial DNA in skin biopsies, may be helpful [81, 82]. Several other diagnostic approaches (e.g. blood microscopy, CD57 levels and lymphocyte transformation test) have not been proven to be clinically useful, mainly due to the lack of specificity [83].

\section{DIFFERENTIAL DIAGNOSIS}

In early stages, borrelial meningo-radiculoneuritis with or without paresis has to be differentiated from mechanical radiculopathy by characteristic CSF findings and neuroimaging. Painful herpes zoster radiculitis is differentiated by typical rash of shingles. Due to CSF inflammation, other causes of acute, subacute and chronic meningitis must be ruled 
out (tick borne encephalitis in endemic areas, other viral, bacterial, tuberculous or fungal meningitis); noninfectious CNS diseases like neurosarcoidosis and leptomeningeal metastases also have to be considered. Facial palsy of borrelial etiology has to be differentiated from idiopathic Bell's palsy, herpes zoster virus infection and, particularly when bilateral, from neurosarcoidosis $[6,25,36]$. Rheumatic polymyalgia is sometimes mentioned in the differential diagnosis of the early Lyme neuroborreliosis. However, rheumatic polymyalgia ("pain in many muscles") is characterized by pronounced pain and/or stiffness in many muscles, and marked fatigue. In addition, in contrast to patients with Lyme neuroborreliosis those with polymyalgia rheumatica as a rule have highly elevated erythrocyte sedimentation rate, high concentration of serum C-reactive protein, anemia and normal CSF findings.

Late Lyme neuroborreliosis may be confused with multiple sclerosis, neurosarcoidosis, intracerebral vasculitis, stroke, psychiatric disorders, pre-senile dementia, and some polyneuropathies. The demonstration of CSF pleocytosis and intrathecal synthesis of borrelial antibodies is crucial to distinguish between these disorders [6, 36].

\section{COINFECTIONS}

Concomitant infections of the CNS with B. burgdorferi s.l. and tick-borne encephalitis virus are possible in endemic regions. There are indications that in an acute stage of the disease symptoms and signs of tick-borne encephalitis are more pronounced, while later on clinical presentation resembles Lyme neuroborreliosis. However, a limited number of case reports on double infection by B. burgdorferi s.l. and tick-borne encephalitis virus of the CNS has been published, and only some of them were based on reliable diagnostic criteria [84 - 87]. In endemic regions patients with double infection should be actively searched for and strict diagnostic criteria for Lyme neuroborreliosis should be followed. Early antibiotic treatment of such patients is required to prevent complications and late manifestations of Lyme borreliosis.

\section{TREATMENT}

Antibiotic therapy in patients with Lyme neuroborreliosis shortens the disease duration [88] and decreases the risk of neurological sequelae. Up to some years ago parenteral ceftriaxone was the drug of choice for treating patients with Lyme neuroborreliosis. It is highly active against B. burgdorferi s.l. in vitro, crosses the blood-brain barrier rather well and has a long serum half-life, which enables once-daily applications. Cefotaxime and penicillin $\mathrm{G}$ in high doses are equally effective as ceftriaxone [6], but are rarely used, because they have to be administered several times a day.

There are convincing evidences, that oral doxycycline has excellent results in vitro against Lyme borreliae, good CNS penetration and good clinical efficacy [89 - 93]. A double-blind randomized trial from Norway, published in 2008, showed that oral doxycycline is as efficient as intravenous ceftriaxone for the treatment of adults with Lyme neuroborreliosis [41]. Therefore, the recommended treatment regimens for patients with Lyme neuroborreliosis is oral doxycycline $100 \mathrm{mg}$ two times a day or ceftriaxone $2 \mathrm{~g}$ once daily intravenously for 14 days. Ceftriaxone is preferred for cases with parenchymal nervous system involvement (encephalitis, myelitis) in early or late stage of the disease, because of lacking data on doxycycline efficacy in such cases; in the late stage the duration could be prolonged to 28 days. Patients with acrodermatitis chronica atrophicans and peripheral neuropathy could be treated with doxycycline for 21 to 28 days [6]. A more prolonged antibiotic treatment of Lyme borreliosis lacks scientific support but may entail an increased risk for severe adverse events [4, 6, 27, 59, 94 - 97].

\section{PROGNOSIS}

Although some early manifestations of Lyme neuroborreliosis would resolve spontaneously, antibiotic treatment speeds up the resolution of symptoms and prevents the development of later complications [6, 88]. Most patients with Lyme neuroborreliosis have very favourable prognosis after adequate therapy [6, 89 - 91], although some reports showed, that a significant number of patients may have residual difficulties, such as fatigue, headache, cognitive impairment, paresthesia, neuropathy, radiculopathy, paresis and residual facial palsy [98 - 100]. Delayed treatment start, more symptoms and findings before treatment and non-complete recovery at 4 months were found as possible predictors for a poorer prognosis in European patients with Lyme neuroborreliosis [101].

\section{CONCLUSION}

Lyme neuroborreliosis is the second most frequent manifestation of Lyme borreliosis in Europe, and the third most common manifestation of the illness in North America, with different clinical characteristics between the continents. For the reliable diagnosis strict diagnostic criteria have to be employed. Appropriate antibiotic treatment (usually with 
oral doxycycline or intravenous ceftriaxone) is successful in most patients with Lyme neuroborreliosis.

\section{CONFLICT OF INTEREST}

The authors confirm that this article content has no conflict of interest.

\section{ACKNOWLEDGEMENTS}

Declared none.

\section{REFERENCES}

[1] Steere AC. Lyme disease. N Engl J Med 2001; 345(2): 115-25. [http://dx.doi.org/10.1056/NEJM200107123450207] [PMID: 11450660]

[2] Stanek G, O’Connell S, Cimmino M, et al. European union concerted action on risk assessment in lyme borreliosis: clinical case definitions for lyme borreliosis. Wien Klin Wochenschr 1996; 108(23): 741-7. [PMID: 8990511]

[3] Stanek G, Fingerle V, Hunfeld KP, et al. Lyme borreliosis: clinical case definitions for diagnosis and management in Europe. Clin Microbiol Infect $2011 ; 17(1): 69-79$.

[http://dx.doi.org/10.1111/j.1469-0691.2010.03175.x] [PMID: 20132258]

[4] Stanek G, Strle F. Lyme borreliosis. Lancet 2003; 362(9396): 1639-47. [http://dx.doi.org/10.1016/S0140-6736(03)14798-8] [PMID: 14630446]

[5] Strle F, Stanek G. Clinical manifestations and diagnosis of lyme borreliosis. Curr Probl Dermatol 2009; 37 : 51-110. [http://dx.doi.org/10.1159/000213070] [PMID: 19367097]

[6] Stanek G, Wormser GP, Gray J, Strle F. Lyme borreliosis. Lancet 2012; 379(9814): 461-73. [http://dx.doi.org/10.1016/S0140-6736(11)60103-7] [PMID: 21903253]

[7] Huppertz HI, Böhme M, Standaert SM, Karch H, Plotkin SA. Incidence of Lyme borreliosis in the Würzburg region of Germany. Eur J Clin Microbiol Infect Dis 1999; 18(10): 697-703. [http://dx.doi.org/10.1007/s100960050381] [PMID: 10584895]

[8] Bacon RM, Kugeler KJ, Mead PS. Surveillance for Lyme disease-United States, 1992-2006. MMWR Surveill Summ 2008; 57(10): 1-9. [PMID: 18830214]

[9] Statistical Yearbook of the Republic of Slovenia 2013. National Institute of Public Health 2013. Available from: http://www.stat.si/ StatWeb/doc/letopis/2013/09-13.pdf

[10] Berglund J, Eitrem R, Ornstein K, et al. An epidemiologic study of Lyme disease in southern Sweden. N Engl J Med 1995; $333(20)$ : $1319-27$. [http://dx.doi.org/10.1056/NEJM199511163332004] [PMID: 7566023]

[11] Wilking H, Stark K. Trends in surveillance data of human Lyme borreliosis from six federal states in eastern Germany, 2009-2012. Ticks Tick Borne Dis 2014; 5(3): 219-24.

[http://dx.doi.org/10.1016/j.ttbdis.2013.10.010] [PMID: 24656810]

[12] Busch U, Hizo-Teufel C, Boehmer R, et al. Three species of Borrelia burgdorferi sensu lato (B. burgdorferi sensu stricto, B. afzelii, and B. garinii) identified from cerebrospinal fluid isolates by pulsed-field gel electrophoresis and PCR J Clin Microbiol 1996; $34(5)$ : $1072-8$. [PMID: 8727878]

[13] Péter O, Bretz AG, Postic D, Dayer E. Association of distinct species of Borrelia burgdorferi sensu lato with neuroborreliosis in Switzerland. Clin Microbiol Infect 1997; 3(4): 423-31. [http://dx.doi.org/10.1111/j.1469-0691.1997.tb00278.x] [PMID: 11864152]

[14] Ryffel K, Péter O, Rutti B, Suard A, Dayer E. Scored antibody reactivity determined by immunoblotting shows an association between clinical manifestations and presence of Borrelia burgdorferi sensu stricto, B. garinii, B. afzelii, and B. Valaisiana in humans. J Clin Microbiol 1999; 37(12): 4086-92. [PMID: 10565936]

[15] Ruzić-Sabljić E, Maraspin V, Lotric-Furlan S, et al. Characterization of Borrelia burgdorferi sensu lato strains isolated from human material in Slovenia. Wien Klin Wochenschr 2002; 114(13-14): 544-50. [PMID: 12422599]

[16] Ornstein K, Berglund J, Bergström S, Norrby R, Barbour AG. Three major Lyme Borrelia genospecies (Borrelia burgdorferi sensu stricto, B. afzelii and B. garinii) identified by PCR in cerebrospinal fluid from patients with neuroborreliosis in Sweden. Scand J Infect Dis 2002 ; 34(5): 341-6. [http://dx.doi.org/10.1080/00365540110080313] [PMID: 12069016]

[17] Strle F, Ruzić-Sabljić E, Cimperman J, Lotric-Furlan S, Maraspin V. Comparison of findings for patients with Borrelia garinii and Borrelia afzelii isolated from cerebrospinal fluid. Clin Infect Dis 2006; 43(6): 704-10. [http://dx.doi.org/10.1086/506936] [PMID: 16912943] 
[18] Pachner AR, Steiner I. Lyme neuroborreliosis: infection, immunity, and inflammation. Lancet Neurol 2007; 6(6): 544-52. [http://dx.doi.org/10.1016/S1474-4422(07)70128-X] [PMID: 17509489]

[19] Fingerle V, Schulte-Spechtel UC, Ruzić-Sabljic E, et al. Epidemiological aspects and molecular characterization of Borrelia burgdorferi s.1. from southern Germany with special respect to the new species Borrelia spielmanii sp. nov. Int J Med Microbiol 2008; 298(3-4): 279-90. [http://dx.doi.org/10.1016/j.ijmm.2007.05.002] [PMID: 17616434]

[20] Ogrinc K, Lotrič-Furlan S, Maraspin V, et al. Suspected early Lyme neuroborreliosis in patients with erythema migrans. Clin Infect Dis 2013; 57(4): 501-9. [http://dx.doi.org/10.1093/cid/cit317] [PMID: 23667259]

[21] Nadelman RB, Wormser GP. Lyme borreliosis. Lancet 1998; 352(9127): 557-65. [http://dx.doi.org/10.1016/S0140-6736(98)01146-5] [PMID: 9716075]

[22] Strle F, Nadelman RB, Cimperman J, et al. Comparison of culture-confirmed erythema migrans caused by Borrelia burgdorferi sensu stricto in New York State and by Borrelia afzelii in Slovenia. Ann Intern Med 1999; 130(1): 32-6. [http://dx.doi.org/10.7326/0003-4819-130-1-199901050-00006] [PMID: 9890847]

[23] Strle F, Ružić-Sabljić E, Logar M, et al. Comparison of erythema migrans caused by Borrelia burgdorferi and Borrelia garinii. Vector Borne Zoonotic Dis 2011; 11(9): 1253-8 [http://dx.doi.org/10.1089/vbz.2010.0230] [PMID: 21612533]

[24] Pachner AR, Steere AC. The triad of neurologic manifestations of Lyme disease: meningitis, cranial neuritis, and radiculoneuritis. Neurology 1985; 35(1): 47-53. [http://dx.doi.org/10.1212/WNL.35.1.47] [PMID: 3966001]

[25] Kristoferitsch W. Neurological manifestations of Lyme borreliosis: clinical definition and differential diagnosis. Scand J Infect Dis Suppl 1991; 77: 64-73. [PMID: 1947814]

[26] Mygland A, Ljøstad U, Fingerle V, Rupprecht T, Schmutzhard E, Steiner I. EFNS guidelines on the diagnosis and management of European Lyme neuroborreliosis. Eur J Neurol 2010; 17(1): 8-16, e1-e4. [http://dx.doi.org/10.1111/j.1468-1331.2009.02862.x] [PMID: 19930447]

[27] Halperin JJ. Nervous system Lyme disease. Handb Clin Neurol 2014; 121: 1473-83. [http://dx.doi.org/10.1016/B978-0-7020-4088-7.00099-7] [PMID: 24365431]

[28] Garin C, Bujadoux C. Paralysie par les tiques. J Med Lyon 1922; 71: 765-7.

[29] Bannwarth A. Chronische lymphocytäre Meningitis, entzündliche Polyneuritis und Rheumatismus. Ein Beitragzum Problem Allergieund Nervensystem in zwei Teilen. Arch Psychiatr Nervenkr 1941; 113: 284-376. [http://dx.doi.org/10.1007/BF02095652]

[30] Steere AC, Grodzicki RL, Kornblatt AN, et al. The spirochetal etiology of Lyme disease. N Engl J Med 1983; 308(13): 733-40. [http://dx.doi.org/10.1056/NEJM198303313081301] [PMID: 6828118]

[31] Pfister HW, Einhäupl K, Preac-Mursic V, Wilske B, Schierz G. The spirochetal etiology of lymphocytic meningoradiculitis of Bannwarth (Bannwarth's syndrome). J Neurol 1984; 231(3): 141-4. [http://dx.doi.org/10.1007/BF00313682] [PMID: 6481420]

[32] Schmidt R, Ackermann R. Meningopolyneuritis (Garin-Bujadoux, Bannwarth) erythema chronicum migrans disease of the nervous system transmitted by ticks. Fortschr Neurol Psychiatr 1985; 53(5): 145-53. [http://dx.doi.org/10.1055/s-2007-1001962] [PMID: 3894183]

[33] Pfister HW, Einhäupl KM, Wilske B, Preac-Mursic V. Bannwarth's syndrome and the enlarged neurological spectrum of arthropod-borne borreliosis. Zentralbl Bakteriol Mikrobiol Hyg [A] 1987; 263(3): 343-7. [http://dx.doi.org/10.1016/S0176-6724(87)80089-5] [PMID: 3591086]

[34] Stiernstedt G, Sköldenberg B, Gårde A, et al. Clinical manifestations of Borrelia infections of the nervous system. Zentralbl Bakteriol Mikrobiol Hyg [A] 1987; 263(3): 289-96. [http://dx.doi.org/10.1016/S0176-6724(87)80079-2] [PMID: 3591077]

[35] Pfister HW, Kristoferitsch W, Meier C. Early neurological involvement (Bannwarth's syndrome). In: Weber K, Burgdorfer W, Eds. Aspects of Lyme borreliosis. Heidelberg: Springer 1993; pp. 152-67. [http://dx.doi.org/10.1007/978-3-642-77614-4_11]

[36] Hansen K, Crone C, Kristoferitsch W. Lyme neuroborreliosis. Handb Clin Neurol 2013; 115: 559-75. [http://dx.doi.org/10.1016/B978-0-444-52902-2.00032-1] [PMID: 23931802]

[37] Dupuis M, Mertens C, Gonsette RE, Nuytten W, Bouffioux J, Dobbelaere F. Meningoradiculitis caused by a spirochete (Borrelia burgdorferi) after arthropod bite. Rev Neurol (Paris) 1985; 141(12): 780-5. [PMID: 3008294]

[38] Ackermann R, Hörstrup P, Schmidt R. Tick-borne meningopolyneuritis (Garin-Bujadoux, Bannwarth). Yale J Biol Med 1984; 57(4): 485-90. [PMID: 6097060]

[39] Ryberg B. Bannwarth's syndrome (lymphocytic meningoradiculitis) in Sweden. Yale J Biol Med 1984; 57(4): 499-503. 
[PMID: 6516452]

[40] Krüger H, Reuss K, Pulz M, et al. Meningoradiculitis and encephalomyelitis due to Borrelia burgdorferi: a follow-up study of 72 patients over 27 years. J Neurol 1989; 236(6): 322-8. [http://dx.doi.org/10.1007/BF00314373] [PMID: 2795099]

[41] Ljøstad U, Skogvoll E, Eikeland R, et al. Oral doxycycline versus intravenous ceftriaxone for European Lyme neuroborreliosis: a multicentre, non-inferiority, double-blind, randomised trial. Lancet Neurol 2008; 7(8): 690-5. [http://dx.doi.org/10.1016/S1474-4422(08)70119-4] [PMID: 18567539]

[42] Hansen K, Lebech AM. The clinical and epidemiological profile of Lyme neuroborreliosis in Denmark 1985-1990. A prospective study of 187 patients with Borrelia burgdorferi specific intrathecal antibody production. Brain 1992; 115(Pt 2): $399-423$. [http://dx.doi.org/10.1093/brain/115.2.399] [PMID: 1606475]

[43] Christen HJ. Lyme neuroborreliosis in children. Ann Med 1996; 28(3): 235-40. [http://dx.doi.org/10.3109/07853899609033125] [PMID: 8811167]

[44] Skogman BH, Croner S, Nordwall M, Eknefelt M, Ernerudh J, Forsberg P. Lyme neuroborreliosis in children: a prospective study of clinical features, prognosis, and outcome. Pediatr Infect Dis J 2008; 27(12): 1089-94. [http://dx.doi.org/10.1097/INF.0b013e31817fd423] [PMID: 19008771]

[45] Lotric-Furlan S, Cimperman J, Maraspin V, et al. Lyme borreliosis and peripheral facial palsy. Wien Klin Wochenschr 1999; 111(22-23): 970-5. [PMID: 10666811]

[46] Halperin JJ. Nervous system Lyme disease. Infect Dis Clin North Am 2008; 22(2): 261-74. [http://dx.doi.org/10.1016/j.idc.2007.12.009] [PMID: 18452800]

[47] Tveitnes D, Øymar K, Natås O. Acute facial nerve palsy in children: how often is it lyme borreliosis? Scand J Infect Dis 2007; 39(5): 425-31. [http://dx.doi.org/10.1080/00365540601105764] [PMID: 17464865]

[48] Arnež M, Ruzić-Sabljić E. Lyme borreliosis and acute peripheral facial palsy in Slovenian children. Pediatr Infect Dis J 2010; $29(2): 182-4$. [http://dx.doi.org/10.1097/INF.0b013e3181bbf28a] [PMID: 19952981]

[49] Donaldson JO, Lewis RA. Lymphocytic meningoradiculitis in the United States. Neurology 1983; 33(11): 1476-9. [http://dx.doi.org/10.1212/WNL.33.11.1476] [PMID: 6685240]

[50] Ackermann R, Rehse-Küpper B, Gollmer E, Schmidt R. Chronic neurologic manifestations of erythema migrans borreliosis. Ann N Y Acad Sci 1988; 539: 16-23.

[http://dx.doi.org/10.1111/j.1749-6632.1988.tb31834.x] [PMID: 3190090]

[51] Oschmann P, Dorndorf W, Hornig C, Schäfer C, Wellensiek HJ, Pflughaupt KW. Stages and syndromes of neuroborreliosis. J Neurol 1998; 245(5): 262-72.

[http://dx.doi.org/10.1007/s004150050216] [PMID: 9617706]

[52] Vandvik B, Sköldenberg B, Stiernstedt G. Tick-borne spirochaetal meningitis, meningoradiculitis and meningoencephalitis. A report on 15 cases identified by demonstration of intrathecal spirochaete-specific IgG antibody response. Acta Neurol Scand 1984; 70: 379-80.

[53] Weder B, Wiedersheim P, Matter L, Steck A, Otto F. Chronic progressive neurological involvement in Borrelia burgdorferi infection. J Neurol 1987; 234(1): 40-3. [http://dx.doi.org/10.1007/BF00314008] [PMID: 3819785]

[54] Kristoferitsch W. Chronic peripheral neuropathy. In: Weber K, Burgdorfer W, Eds. Aspects of Lyme borreliosis. Heidelberg: Springer 1993; pp. 219-27. [http://dx.doi.org/10.1007/978-3-642-77614-4_16]

[55] Kindstrand E, Nilsson BY, Hovmark A, Pirskanen R, Asbrink E. Peripheral neuropathy in acrodermatitis chronica atrophicans - a late Borrelia manifestation. Acta Neurol Scand 1997; 95(6): 338-45.

[http://dx.doi.org/10.1111/j.1600-0404.1997.tb00222.x] [PMID: 9228267]

[56] Halperin JJ. Nervous system manifestations of Lyme disease. Rheum Dis Clin North Am 1989; 15(4): 635-47. [PMID: 2555847]

[57] Logigian EL, Kaplan RF, Steere AC. Chronic neurologic manifestations of Lyme disease. N Engl J Med 1990; $323(21): 1438-44$. [http://dx.doi.org/10.1056/NEJM199011223232102] [PMID: 2172819]

[58] Halperin JJ, Heyes MP. Neuroactive kynurenines in Lyme borreliosis. Neurology 1992; 42(1): 43-50. [http://dx.doi.org/10.1212/WNL.42.1.43] [PMID: 1531156]

[59] Wormser GP, Dattwyler RJ, Shapiro ED, et al. The clinical assessment, treatment, and prevention of lyme disease, human granulocytic anaplasmosis, and babesiosis: clinical practice guidelines by the Infectious Diseases Society of America. Clin Infect Dis 2006; 43(9): 1089-134. [http://dx.doi.org/10.1086/508667] [PMID: 17029130]

[60] Halperin JJ. Nervous system Lyme disease. J R Coll Physicians Edinb 2010; 40(3): 248-55. [http://dx.doi.org/10.4997/JRCPE.2010.314] [PMID: 21127770]

[61] Halperin JJ. Neurologic manifestations of lyme disease. Curr Infect Dis Rep 2011; 13(4): 360-6. 
[http://dx.doi.org/10.1007/s11908-011-0184-x] [PMID: 21484219]

[62] Hansen K, Lebech AM. Lyme neuroborreliosis: a new sensitive diagnostic assay for intrathecal synthesis of Borrelia burgdorferi-specific immunoglobulin G, A, and M. Ann Neurol 1991; 30(2): 197-205. [http://dx.doi.org/10.1002/ana.410300212] [PMID: 1897911]

[63] Brouqui P, Bacellar F, Baranton G, et al. Guidelines for the diagnosis of tick-borne bacterial diseases in Europe. Clin Microbiol Infect 2004; 10(12): 1108-32. [http://dx.doi.org/10.1111/j.1469-0691.2004.01019.x] [PMID: 15606643]

[64] Preac Mursic V, Wilske B, Schierz G, Pfister HW, Einhäupl K. Repeated isolation of spirochetes from the cerebrospinal fluid of a patient with meningoradiculitis Bannwarth. Eur J Clin Microbiol 1984; 3(6): 564-5. [http://dx.doi.org/10.1007/BF02013623] [PMID: 6526024]

[65] Wilske B, Schierz G, Preac-Mursic V, et al. Intrathecal production of specific antibodies against Borrelia burgdorferi in patients with lymphocytic meningoradiculitis (Bannwarth’s syndrome). J Infect Dis 1986; 153(2): 304-14. [http://dx.doi.org/10.1093/infdis/153.2.304] [PMID: 3944483]

[66] Wilske B, Bader L, Pfister HW, Preac-Mursic V. Diagnosis of Lyme neuroborreliosis. Detection of intrathecal antibody formation. Fortschr Med 1991; 109(22): 441-6. [PMID: 1937323]

[67] Kaiser R. Intrathecal immune response in neuroborreliosis: importance of cross-reactive antibodies. Zentralbl Bakteriol 1995; $282(3)$ : 303-14. [http://dx.doi.org/10.1016/S0934-8840(11)80131-3] [PMID: 7549163]

[68] Cerar T, Ogrinc K, Strle F, Ruzić-Sabljić E. Humoral immune responses in patients with Lyme neuroborreliosis. Clin Vaccine Immunol 2010; 17(4): 645-50. [http://dx.doi.org/10.1128/CVI.00341-09] [PMID: 20164248]

[69] Stanek G, Lusa L, Ogrinc K, Markowicz M, Strle F. Intrathecally produced IgG and IgM antibodies to recombinant VlsE, VlsE peptide, recombinant $\mathrm{OspC}$ and whole cell extracts in the diagnosis of Lyme neuroborreliosis. Med Microbiol Immunol (Berl) 2014; 203(2): 125-32. [http://dx.doi.org/10.1007/s00430-013-0322-1] [PMID: 24363169]

[70] Reiber H, Lange P. Quantification of virus-specific antibodies in cerebrospinal fluid and serum: sensitive and specific detection of antibody synthesis in brain. Clin Chem 1991; 37(7): 1153-60.

[PMID: 1855284]

[71] Felgenhauer K. Barrier concepts and CSF analysis. J Neurol 1992; 239(2): 59-60. [http://dx.doi.org/10.1007/BF00862971] [PMID: 1552303]

[72] Reiber H, Peter JB. Cerebrospinal fluid analysis: disease-related data patterns and evaluation programs. J Neurol Sci 2001; 184(2): 101-22. [http://dx.doi.org/10.1016/S0022-510X(00)00501-3] [PMID: 11239944]

[73] Karlsson M, Hovind-Hougen K, Svenungsson B, Stiernstedt G. Cultivation and characterization of spirochetes from cerebrospinal fluid of patients with Lyme borreliosis. J Clin Microbiol 1990; 28(3): 473-9. [PMID: 2324275]

[74] Cerar T, Ogrinc K, Cimperman J, Lotric-Furlan S, Strle F, Ruzić-Sabljić E. Validation of cultivation and PCR methods for diagnosis of Lyme neuroborreliosis. J Clin Microbiol 2008; 46(10): 3375-9. [http://dx.doi.org/10.1128/JCM.00410-08] [PMID: 18716226]

[75] Rupprecht TA, Pfister HW, Angele B, Kastenbauer S, Wilske B, Koedel U. The chemokine CXCL13 (BLC): a putative diagnostic marker for neuroborreliosis. Neurology 2005; 65(3): 448-50.

[http://dx.doi.org/10.1212/01.wnl.0000171349.06645.79] [PMID: 16087912]

[76] Ljøstad U, Mygland A. CSF B-lymphocyte chemoattractant (CXCL13) in the early diagnosis of acute Lyme neuroborreliosis. J Neurol 2008; 255(5): $732-7$. [http://dx.doi.org/10.1007/s00415-008-0785-y] [PMID: 18344056]

[77] Schmidt C, Plate A, Angele B, et al. A prospective study on the role of CXCL13 in Lyme neuroborreliosis. Neurology 2011; 76(12): 1051-8. [http://dx.doi.org/10.1212/WNL.0b013e318211c39a] [PMID: 21422457]

[78] Cerar T, Ogrinc K, Lotrič-Furlan S, et al. Diagnostic value of cytokines and chemokines in lyme neuroborreliosis. Clin Vaccine Immunol 2013; 20(10): 1578-84. [http://dx.doi.org/10.1128/CVI.00353-13] [PMID: 23945160]

[79] Asbrink E, Hovmark A. Early and late cutaneous manifestations in Ixodes-borne borreliosis (erythema migrans borreliosis, Lyme borreliosis). Ann N Y Acad Sci 1988; 539: 4-15.

[http://dx.doi.org/10.1111/j.1749-6632.1988.tb31833.x] [PMID: 3056204]

[80] Asbrink E, Hovmark A, Weber K. Acrodermatitis chronica atrophicans. In: Weber K, Burgdorfer W, Eds. Aspects of Lyme borreliosis. Heidelberg: Springer 1993; pp. 193-204. [http://dx.doi.org/10.1007/978-3-642-77614-4_14]

[81] Brettschneider S, Bruckbauer H, Klugbauer N, Hofmann H. Diagnostic value of PCR for detection of Borrelia burgdorferi in skin biopsy and urine samples from patients with skin borreliosis. J Clin Microbiol 1998; 36(9): 2658-65.

[PMID: 9705410] 
[82] Brandt FC, Ertas B, Falk TM, Metze D, Böer-Auer A. Genotyping of Borrelia from formalin-fixed paraffin-embedded skin biopsies of cutaneous borreliosis and tick bite reactions by assays targeting the intergenic spacer region, ospA and ospC genes. Br J Dermatol 2014 ; 171(3): 528-43.

[http://dx.doi.org/10.1111/bjd.12855] [PMID: 24471698]

[83] Dessau RB, Fingerle V, Gray J, et al. The lymphocyte transformation test for the diagnosis of Lyme borreliosis has currently not been shown to be clinically useful. Clin Microbiol Infect 2014; 20(10): O786-7. [http://dx.doi.org/10.1111/1469-0691.12583] [PMID: 24520912]

[84] Kristoferitsch W, Stanek G, Kunz C. Doppelinfektion mit Frühsommermeningoenzephalitis-(FSME-) Virus und Borrelia burgdorferi. Dtsch Med Wochenschr 1986; 111(22): 861-4. [http://dx.doi.org/10.1055/s-2008-1068546] [PMID: 3011378]

[85] Oksi J, Viljanen MK, Kalimo H, et al. Fatal encephalitis caused by concomitant infection with tick-borne encephalitis virus and Borrelia burgdorferi. Clin Infect Dis 1993; 16(3): 392-6. [http://dx.doi.org/10.1093/clind/16.3.392] [PMID: 8452951]

[86] Cimperman J, Maraspin V, Lotric-Furlan S, et al. Concomitant infection with tick-borne encephalitis virus and Borrelia burgdorferi sensu lato in patients with acute meningitis or meningoencephalitis. Infection 1998; 26(3): 160-4. [http://dx.doi.org/10.1007/BF02771842] [PMID: 9646107]

[87] Cimperman J, Maraspin V, Lotric-Furlan S, Ruzić-Sabljić E, Avsic-Zupanc T, Strle F. Double infection with tick borne encephalitis virus and Borrelia burgdorferi sensu lato. Wien Klin Wochenschr 2002; 114(13-14): 620-2. [PMID: 12422613]

[88] Steere AC, Pachner AR, Malawista SE. Neurologic abnormalities of Lyme disease: successful treatment with high-dose intravenous penicillin. Ann Intern Med 1983; 99(6): 767-72. [http://dx.doi.org/10.7326/0003-4819-99-6-767] [PMID: 6316826]

[89] Karlsson M, Hammers-Berggren S, Lindquist L, Stiernstedt G, Svenungsson B. Comparison of intravenous penicillin G and oral doxycycline for treatment of Lyme neuroborreliosis. Neurology 1994; 44(7): 1203-7. [http://dx.doi.org/10.1212/WNL.44.7.1203] [PMID: 8035916]

[90] Karlsson M, Hammers S, Nilsson-Ehle I, Malmborg AS, Wretlind B. Concentrations of doxycycline and penicillin G in sera and cerebrospinal fluid of patients treated for neuroborreliosis. Antimicrob Agents Chemother 1996; 40(5): 1104-7. [PMID: 8723448]

[91] Dotevall L, Hagberg L. Successful oral doxycycline treatment of Lyme disease-associated facial palsy and meningitis. Clin Infect Dis 1999; 28(3): 569-74. [http://dx.doi.org/10.1086/515145] [PMID: 10194080]

[92] Borg R, Dotevall L, Hagberg L, et al. Intravenous ceftriaxone compared with oral doxycycline for the treatment of Lyme neuroborreliosis. Scand J Infect Dis 2005; 37(6-7): 449-54. [http://dx.doi.org/10.1080/00365540510027228] [PMID: 16012005]

[93] Hunfeld KP, Brade V. Antimicrobial susceptibility of Borrelia burgdorferi sensu lato: what we know, what we don't know, and what we need to know. Wien Klin Wochenschr 2006; 118(21-22): 659-68. [http://dx.doi.org/10.1007/s00508-006-0693-z] [PMID: 17160604]

[94] Klempner MS, Hu LT, Evans J, et al. Two controlled trials of antibiotic treatment in patients with persistent symptoms and a history of Lyme disease. N Engl J Med 2001; 345(2): 85-92. [http://dx.doi.org/10.1056/NEJM200107123450202] [PMID: 11450676]

[95] Wormser GP, Nowakowski J, Nadelman RB. Duration of treatment for Lyme borreliosis: time for a critical reappraisal. Wien Klin Wochenschr 2002; 114(13-14): 613-5. [PMID: 12422611]

[96] Krupp LB, Hyman LG, Grimson R, et al. Study and treatment of post Lyme disease (STOP-LD): a randomized double masked clinical trial. Neurology 2003; 60(12): 1923-30. [http://dx.doi.org/10.1212/01.WNL.0000071227.23769.9E] [PMID: 12821734]

[97] Oksi J, Nikoskelainen J, Hiekkanen H, et al. Duration of antibiotic treatment in disseminated Lyme borreliosis: a double-blind, randomized, placebo-controlled, multicenter clinical study. Eur J Clin Microbiol Infect Dis 2007; 26(8): 571-81. [http://dx.doi.org/10.1007/s10096-007-0340-2] [PMID: 17587070]

[98] Cimperman J, Maraspin V, Lotric-Furlan S, Ruzić-Sabljić E, Strle F. Lyme meningitis: a one-year follow up controlled study. Wien Klin Wochenschr 1999; 111(22-23): 961-3. [PMID: 10666809]

[99] Berglund J, Stjernberg L, Ornstein K, Tykesson-Joelsson K, Walter H. 5-y Follow-up study of patients with neuroborreliosis. Scand J Infect Dis 2002; 34(6): 421-5. [http://dx.doi.org/10.1080/00365540110080421] [PMID: 12160168]

[100] Eikeland R, Mygland A, Herlofson K, Ljøstad U. European neuroborreliosis: quality of life 30 months after treatment. Acta Neurol Scand $2011 ; 124(5): 349-54$ [http://dx.doi.org/10.1111/j.1600-0404.2010.01482.x] [PMID: 21303350] 
[101] Eikeland R, Mygland A, Herlofson K, Ljøstad U. Risk factors for a non-favorable outcome after treated European neuroborreliosis. Acta Neurol Scand 2013; 127(3): 154-60. [http://dx.doi.org/10.1111/j.1600-0404.2012.01690.x] [PMID: 22690926]

Received: October 22, 2015

Revised: December 16, 2015

Accepted: December 16, 2015

(C) Ogrinc and Maraspin; Licensee Bentham Open.

This is an open access article licensed under the terms of the Creative Commons Attribution-Non-Commercial 4.0 International Public License (CC BY-NC 4.0) (https://creativecommons.org/licenses/by-nc/4.0/legalcode), which permits unrestricted, non-commercial use, distribution and reproduction in any medium, provided the work is properly cited. 